\title{
TV/Series
}

$4 \mid 2013$

Écho et reprise dans les séries télévisées (II) : Re-

présentations -- enjeux socio-culturels, politiques et idéologiques de la reprise

\section{Echoes of the "War on Terror" and Post 9-11 Culture in Battlestar Galactica (Syfy Channel, 2003-2009)}

\section{Donna Spalding Andréolle}

\section{(2) OpenEdition}

\section{Journals}

Electronic version

URL: http://journals.openedition.org/tvseries/744

DOI: 10.4000/tvseries.744

ISSN: 2266-0909

\section{Publisher}

GRIC - Groupe de recherche Identités et Cultures

\section{Electronic reference}

Donna Spalding Andréolle, "Echoes of the "War on Terror" and Post 9-11 Culture in Battlestar Galactica (Syfy Channel, 2003-2009) », TV/Series [Online], 4 | 2013, Online since 15 December 2013, connection on 19 April 2019. URL : http://journals.openedition.org/tvseries/744 ; DOI : 10.4000/tvseries.744

\section{cc)}

TV/Series est mis à disposition selon les termes de la licence Creative Commons Attribution - Pas d'Utilisation Commerciale - Pas de Modification 4.0 International. 


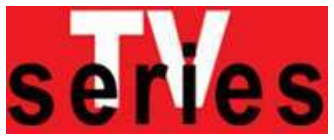

\section{Echoes of the "War on Terror" and Post 9-11 Culture in Battlestar Galactica (Syfy Channel, 2003-2009)}

Donna SPALDING ANDRÉOLLE

Ronald D. Moore's "remade" version of Battlestar Galatica marks a return to a resolutely militaristic form of science fiction which can perhaps be best understood if one is to reflect on how the series resonates in the context of "post 9-11" America. While some of the echoes of American culture are obvious to the viewer, such as the "federation" of colonies (twelve plus the missing thirteenth colony of Earth), other elements of the story arc can be perceived as indirect references to the War on Terror and/or the actual attacks of September $11^{\text {th }}$ 2001. One such visual is in the opening credit scene of all four seasons: the moment when Six protects Baltar from the nuclear explosion on Caprica, with the blast arriving horizontally through a pane-glassed façade, reminiscent of what victims must have seen in the World Trade towers as the planes hit. Another visual shown occasionally in all four seasons but more often in Season 4 is the wall of commemoration on the battleship, again bearing a striking resemblance to the wall in New York City mourning the lost and the missing in the days following the attacks. Beyond these specific references, this study will attempt to analyze how the concept of the "Other as Us" characterized by the physical appearance of the Cylons (as well as their origin as creations of humanity) creates not only a permanent form of paranoia - fundamental to the scenario itself - but more importantly in the viewer, thus transmitting a message of one of the most dangerous aspects of America's war against terrorists both inside and outside the United States and its toxic influence on the democratic/utopian ideal. This, coupled with an examination of the power struggles revolving around Admiral Adama, President Laura Roslin and Gaius Baltar, will illustrate the delicate questions the series poses on the United States' management of a "global" war and its meanings within contemporary America.

$\mathrm{T}$

The television series Battlestar Galatica was originally created in 1978 by Glen Larson and re-imagined by Ronald D. Moore first as a mini-series for the Syfy channel in 2003 (which we will refer to as "the pilot" in this paper) before being developed to include 73 episodes over 4 seasons. It marks a return to a resolutely militaristic form of science fiction which can perhaps be best understood if one is to reflect on how the series resonates in the context of "post 9-11" America. There is no need to remind the audience of the events of September 11, 2001, the trauma of which was shared globally as television cameras and eye-witnesses recording the horror captured the collapse of the World Trade Center twin towers as well as the "killer cloud" of dust and debris which poured through the streets and covered everything and everyone in a thick layer of gray ash. Although two other planes struck two other sites (the Pentagon and a field in Pennsylvania), the spectacular nature of the events in New York City has remained the most mediatized - and thus remembered dimension of what has now become more commonly known as " $9 / 11$ " in the American culture. " $9 / 11$ " is more than the events themselves; it is rather what cultural historian Richard Slotkin would call a mythic icon ${ }^{1}$

${ }^{1}$ Richard Slotkin develops this concept in his second work on the myth of the Frontier The Fatal Environment: The Myth of the Frontier in the Age of Industrialization 1800-189o, when discussing how the Battle of Little Big Horn became Custer's Last Stand in the 
or what Jeffrey Melnick in his book 9/11 Culture: America under Construction calls a cultural formation, "a site where important social and political institutions, rhetorical practices and personal behaviors overlap and combine to create a threshold level of cultural energy that comes to help define its historical moment in some significant manner ${ }^{2}$." We will consider that Battlestar Galactica contributes to the building of this site, as screenwriter Ronald D. Moore and producer David Eick explore visually, rhetorically and allegorically how the trauma of $9 / 11$ and the ensuing War on Terror have impacted American ideals and cultural practices. This paper will therefore seek to demonstrate how the series plays on "sublimated 9/11 fears3" through the use of image and discourse, and ask the question of whether Battlestar Galactica actually contributes to the cultural narrative of post-9/11 America or if, on the contrary, it can be viewed as a counter-narrative underlining the "political ambiguity and moral instability initiated in September 2001 and extended by the [...] wars in Afghanistan and Iraq4."

While Ronald D. Moore declares in his Battlestar Galactica "series bible" that the intention behind the remake of the original 1978 series was to write an "allegory for our own society, our own people" and that "it should be immediately recognizable to any member of the audience," when questioned about whether or not the show was specifically about 9/11 and the War on Terror he responded that the references were more to "Vichy France, Vietnam, the West Bank and various other occupations" as well as to World War II ${ }^{5}$. Yet we will posit here that the story of 9/11 (which includes the War on Terror) is in fact the nexus of the discourse and visuals of war connected to American military engagement in the $20^{\text {th }}$ and $21^{\text {st }}$ centuries: George W. Bush, for example, recycled the expression "Day of Infamy"

popular culture. The fabrication of a mythic icon involves the development of networks of meaning linking breaking news events which are then woven into a story resonating socially, ideologically and historically through a culture. See Slotkin, The Fatal Environment: The Myth of the Frontier in the Age of Industrialization 180o-189o, New York, Harper Perennial, 1985, chapter 18, "To the Last Man: Assembling the Last Stand Myth, 1876".

2 Jeffrey Melnick, 9/11 Culture: America under Construction, Malden, Mass., WileyBlackwell, 2009, p. 114 (Kindle edition).

3 Melnick, p. 2027. The actual quote in context : "In early 2008 when The Boston Globe reviewed the monster movie Cloverfield, the paper included its usual sidebar with the movie's basic stats, including running time, director, and why it received its PG-13 rating: 'violence, terror, disturbing images; sublimated 9/11 fears."'

4 Steven Rawle, "Re-imagining Terror in Battlestar Galactica: Negotiating Real and Fantasy in Battlestar Galactica's Political Metaphor" in Battlestar Galactica: Investigating Flesh, Spirit and Steel, ed. Roz Kaveney and Jennifer Stoy, New York, IB Tauris, 2010, p. 137 (Kindle edition)

5 Moore quoted in David Bassom, Battlestar Galactica: The Official Companion Season 3 London, Titan Books, p. 31. 
(originally used by F.D.R. in reference to Pearl Harbor) to describe the attacks of September $11^{\text {th}}$; the media baptized the smoking hole left by the twin towers "Ground Zero"(a technical term for the location of an atomic bomb's initial impact), specifically calling to mind the nuking of Hiroshima; the scene where Cylons on Caprica bulldoze bodies into a mass grave (The Plan ${ }^{6}$ ), or the scene where Adama ponders the rows of body bags on the flight deck remind the viewer of the price of war on both civilian and military populations, a sacrifice commented upon by Adama in surprisingly non-militaristic terms in the pilot episode. Perhaps it is possible to imagine here that Moore is choosing to show the body bags that Americans were not allowed to see in the context of the War on Terror, the Bush administration forbidding the presence of camera crews on military bases where the dead were brought back - a lesson learned from the Vietnam War. One can also note that the character Sharon Valerii a.k.a. "Boomer" a.k.a. Number 8, who is the multiple Cylon shown in the pre-credit sequence about the Cylons ${ }^{7}$, is Asian, a visual reminder of the "problem" of distinguishing the enemy combatant from the civilian collaborator in Vietnam and which led to the atrocity of the My Lai massacre (and we can add here that this same ambiguity existed in WW2 with Japanese Americans); this is underlined in the series by Boomer's ambiguous role first as a human, then as the Cylon sleeper agent who tries to assassinate Adama, then as the matrix of future human-Cylon civilization when she gives birth to Hera. The problem of distinguishing the enemy also points to the War on Terror, notably the hunt for Bin Laden then for Saddam Hussein: the American public was told that Saddam had many "look-alikes" which made it easy for him to hide and hard for the Army to find him (see Plate 1); and of course Islamist terrorists were systematically portrayed in the media as bearded, turban-wearing males who were hard to distinguish from the "real" target. In Battlestar Galactica the concept of a limited number of Cylons duplicating themselves indefinitely plays into the essentializing stance that the racial and/or ideological Other has no existence as an individual.
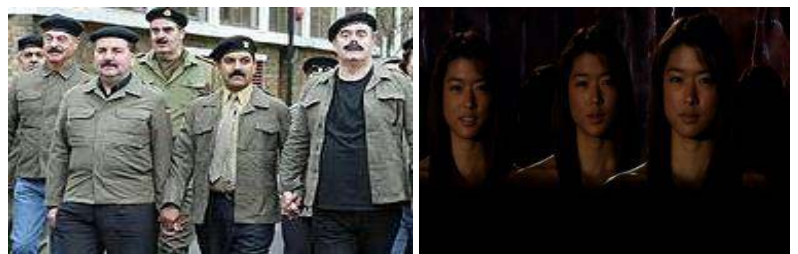

Plate 1: Saddam Hussein "look alikes" / Copies of Number 8

\footnotetext{
${ }^{6}$ The Plan is a TV movie produced in 2009 after the end of the series.

7 In this sequence we see a split screen with two images of Boomer and the text-over "There are many copies.”
} 
The series is also literally peppered with other diverse references to 9/11 and the War on Terror: after Aaron Doral (Cylon Number 5) blows himself up on Galactica (1.6), there are several shots of the badly burned soldiers which recall the firefighters of the NYFD (see Plate 2); the brutal torture of Gina (one of the versions of Number 6) in Season 2 episode 5, the waterboarding of Leoben Conoy (Cylon Number 2) in Season 1 episode 9 are illustrations of the dehumanization which characterizes the War on Terror "in which enemy combatants are defined intellectually by their politics rather than visibly by the uniform they wear ${ }^{8}$."

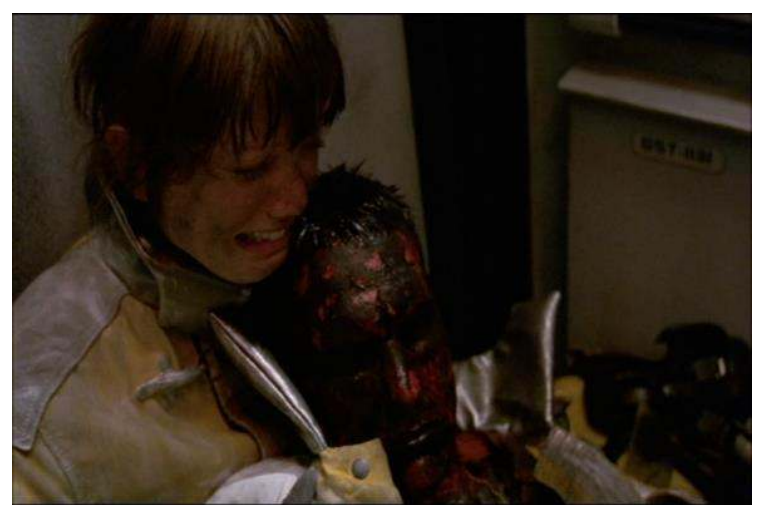

Plate 2: Burn victim on Galactica (1.6), visual echo of 9-11

Cavil (a.k.a. Number 1) makes cynical remarks throughout The Plan (TV movie produced in 2009 after the end of the series) such as "2, let's get this genocide started” or when convincing Number 5 , Aaron Doral, to become a suicide bomber says "They call this a suicide vest. But I think that undersells all the homicide that goes with it, don't you?" Obviously the idea being conveyed here is that the Cylons do not value life and have no qualms about killing others even if it entails their own death as long as it is for a higher purpose; repeated remarks of this nature seemingly "echo" American comments on Islamist terrorists. Cavil can of course be perceived by the viewer as a "toaster 9 " version of Bin Laden, even if we can wonder why the character in Moore's Battlestar Galactica is ultimately portrayed as a Godless manipulator of his fellow Cylons whose superhuman powers are considerably weakened by their blind faith in the one true God (the scene in which

${ }^{8}$ Rawle, p. 143

${ }^{9}$ For the non-initiates of Battlestar Galactica, "toaster" is a pejorative term for Cylon. 
Leoben/Number 2 is tortured by Starbuck is the perfect illustration of this dichotomy; see Plate 3).

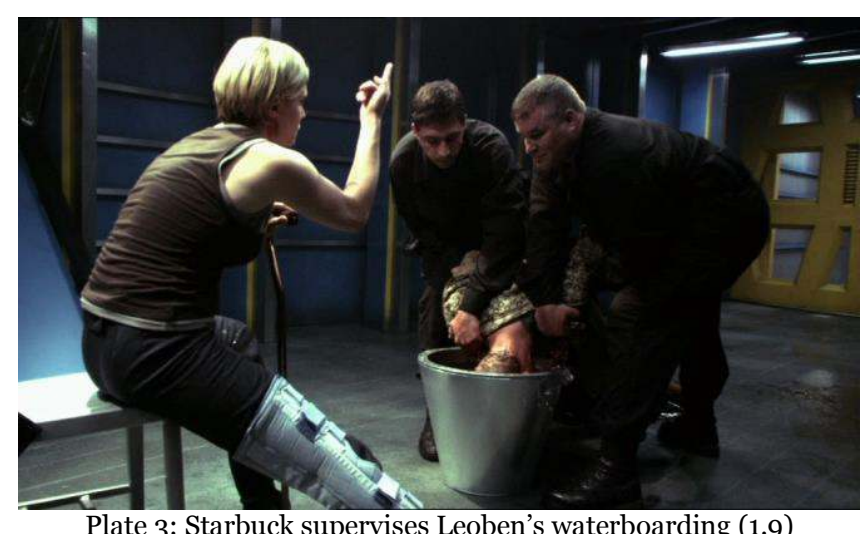

There are other interesting textual references to the general context of the Bush administration years revolving around the character of Laura Roslin. For example, we are told that Roslin was the forty-third cabinet member in line of succession (George W. Bush was the $43^{\text {rd }}$ president), and her ability to serve as president is called into question during her first confrontations of power with Adama in which Saul Tigh asks Adama why he is taking orders from a school teacher. In the early days of her much contested presidency she "waffles" on various issues and makes what seem to be ludicrous statements such as "we lost the war, we have to make babies" (1.1); and like George W. Bush, she is literally thrust into the role of Commander-in-Chief in the wake of a national, if not global, catastrophe. One cannot but be reminded of the Bush/Cheney/Rumsfeld combination when watching Laura Roslin slug it out with Adama and Tigh, the two men crusty old veterans of another major war seeking to control, perhaps even prey on, the inexperienced leader. Pushing the allegory even further, Ronald Moore turns Roslin into a "born-again pagan" when she proclaims herself the mysterious dying leader who will take her people to Earth, an event which has been prophesized in the Kobol scriptures. In an ironic turn of the tables, Roslin, guided by a new-found religious fervor (again, an echo of George W. Bush's claim of being a born-again Christian), eventually becomes the neo-conservative voice of the fleet while Adama assumes the role of civil rights advocate in the hearings around the sabotaging of Galactica's water supply (1.2), echoed by his son's stance during Gaius Baltar's trial (3.18-20). Baltar's trial in particular strangely reminds the viewer of the "kangaroo courts" set up 
to try Guantanamo Bay detainees for treason, perhaps a veiled reference to the criticism in the press at the time ${ }^{10}$.

Beyond the punctual visual and discursive elements which point to Battlestar Galactica's function as a commentary on the War on Terror, it is possible to discern more telling aspects of the angst of 9/11 culture resonating through the series. For this part of my analysis I am going to turn to the ideas expressed by militant feminist Susan Faludi in her 2008 work entitled The Terror Dream: Fear and Fantasy in Post 9/11 America ${ }^{11}$. Faludi's point of departure is a quote, found on the Internet site "mensaction.net," made by its director who equates the collapse of the twin towers with the "emasculation" of American supremacy:

The phallic symbol of America has been ripped off, and at its base was a large smoldering vagina, the true symbol of the American culture, for it is the western culture that represents the feminine materialistic principle, and it is at its extreme in America. (quoted in Faludi, p. 12)

Faludi wonders how "a nation attacked precisely because of its imperial pre-eminence responded by fixating on its weakness and ineffectuality. Even more peculiar was our displacement of that fixation into the domestic realm, into a sexualized struggle between depleted masculinity and overbearing womanhood ${ }^{12}$." Faludi goes on to analyse how the manufacturing of the story of $9 / 11$ revolved around the creation of male hero figures (firemen, policemen, the male passengers of United flight 93...) and of female victims, either shown being rescued by the aforesaid heroes or mourning in their homes, in the company of their small fatherless children; she also notes the return of the superhero movie genre in the wake of $9 / 11$ as another effort at compensation for the emasculating effects of the September $11^{\text {th }}$ events. If we "read" Battlestar Galactica using the prism of Faludi's interpretation, we can view the series as a case in point: the story arc begins with the decommissioning of the Galactica, in the process of becoming a museum for school children - one might say a form of emasculation of military might (underlined by the fact that the Secretary of Education is a woman). The antiquated uselessness, or

\footnotetext{
${ }^{10}$ Extract from William Safire's article entitled "Seizing Dictatorial Power" published in the New York Times on November 15, 2001: "[Bush's] kangaroo court can conceal evidence by citing national security, make up its own rules, find a defendant guilty even if a third of the officers disagree, and execute the alien with no review by any civilian court. No longer does the judicial branch and an independent jury stand between the government and the accused. In lieu of those checks and balances central to our legal system, non-citizens face an executive that is now investigator, prosecutor, judge, jury and jailer or executioner. In an Orwellian twist, Bush's order calls this Soviet-style abomination "a full and fair trial." For full text go to http://www.nytimes.com/2001/11/15/opinion/15SAFI.html downloaded December 152001.

${ }^{11}$ Susan Faludi, The Terror Dream: Fear and Fantasy in Post-9/11 America, New York, Picador, 2008 (Kindle edition).
}

${ }^{12}$ Faludi, p. 12. 
ineffectuality, to use Faludi's term, of the battleship is highlighted by Aaron Doral's comments as he guides the press through the corridors of Galactica. Ironically, it is the battleship's low-tech shortcomings that will save it from the annihilation of the other battleships of the fleet. The unexpected Cylon attack and the total devastation of colonial civilization are of course a scathing humiliation for the military, especially since it is the work of "toasters," i.e. man-made machines whose rebellion has been crushed 40 years before the present of the narration. The disbelief of the colonial forces and populations, as well as their incapacity to understand the extent of Cylon hatred towards humanity, are not without resemblance to what could be read in the press about $9 / 11$ in the weeks that followed the attacks ${ }^{13}$.

As for the concept of a "sexualized struggle between depleted masculinity and overbearing womanhood," Battlestar Galactica offers characters who illustrate the dangers of powerful females, especially if we examine certain "couples" we are shown: Adama/Roslin, Saul/Ellen Tigh, Baltar/Number Six and Apollo/Starbuck. Whereas Adama, Tigh and Baltar are in positions of what would normally represent male authority (military for the first two, scientific for Baltar), they are weakened by self-doubt and guilt, albeit for different reasons: Adama mourns for his lost son Zack and is accused of causing Zack's death by his other son, Lee - a.k.a. Apollo - and certain scenes suggest his failed marriage is due to his unconditional devotion to his military career; Tigh is an alcoholic, which has a devastating effect on his judgment and credibility as a commanding officer (re. the scene where he fights with Starbuck at a poker game); Baltar has betrayed the human race and uses his knowledge to protect Cylons. While Apollo appears to be a much stronger character in the beginning (the heroic Viper pilot and respected CAG), his development is characterized by indecision, flipflopping in loyalty between Adama and Roslin, an uncertain relationship with Starbuck and major "daddy issues." The women characters, on the other hand, tend to wield determinate levels of power in different ways: Number Six and Ellen Tigh (also in fact a Cylon) manipulate men sexually, embodying the stereotype of the "man-eater" but with the twist of being highly intelligent and politically driven to achieve the Cylon agenda (see Plate 4); Laura Roslin progressively affirms her status as the leader of the colonies including through the use of violence - for example she airlocks Leoben without hesitation (although she questioned the validity of torturing him), plots to assassinate Admiral Cain and approves of a plan which would provoke the genocide of the Cylons.

${ }^{13}$ In particular several articles published in a special issue of Newsweek in October 2001. Faludi also makes a convincing case of how the media developed these themes, notably in chapters 1 and 2. 


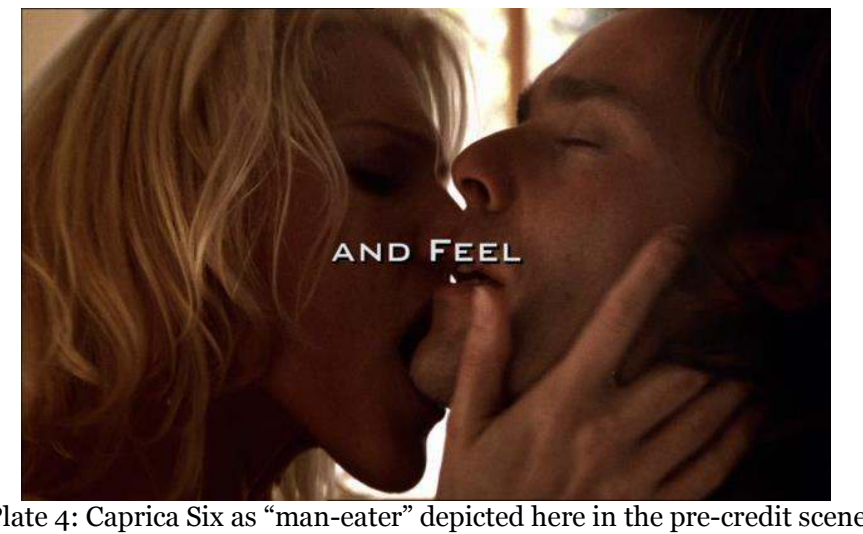

The ultimate threat to masculinity, however, and the best example of "overbearing womanhood" is Starbuck (Kara Thrace), the best Viper pilot of the colonial fleet. It is interesting to note here that in the original series Starbuck was a male character (as was Boomer, also a female character in the remake) and this particular transformative choice was a controversial one when the series was aired, with massive fan protest of Moore's choice. Yet the Starbuck of the re-imagined series incarnates what I would call the "female man"14", a cigarsmoking, poker-playing, heavy drinking muscular young woman with a definite attitude problem which lands her in the brig on a regular basis (see Plate 5).

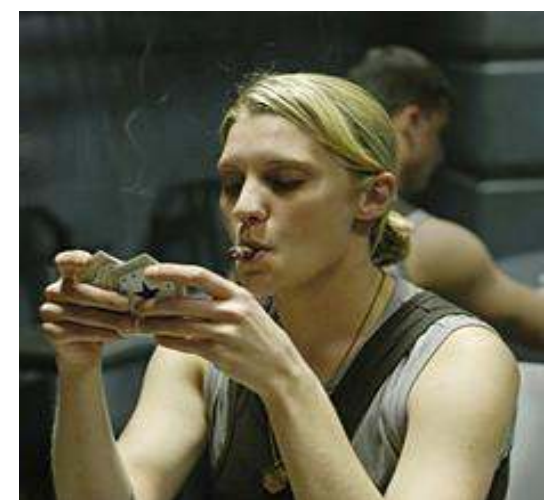

Plate 5: The character of Starbuck as the "female man"

${ }^{14}$ I am referring to the title of a famous feminist science fiction novel written by Joanna Russ and published in 1972. 
Even though she is not impervious to love or to maternal feelings which make her seem at least a little fallible, she remains one of the strongest characters and definitely embodies gender issues not only within the science fiction genre itself but also within the contemporary society being mirrored in the series. Last but not least, the most threatening female character by far is Admiral Helena Cain who commands the battlestar Pegasus and who has also miraculously survived the holocaust. Cain's ruthlessness is fully developed in the film Razor (produced as a "bridge" between Seasons 2 and 3) in which we see her, for example, shoot her X-O in the head when he refuses to execute one of her orders (see Plate 6).

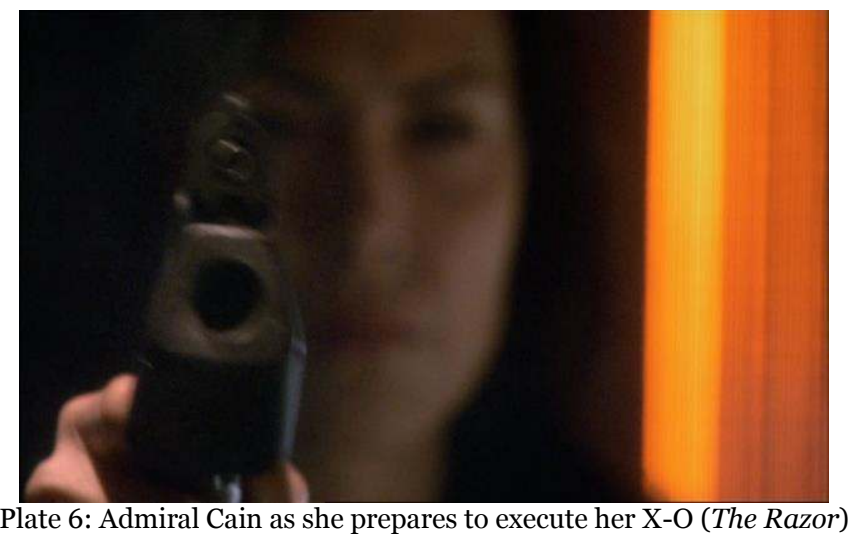

She is in many ways the ultimate career bitch who has achieved the highest command in the colonial fleet by terrorizing her crew and officers into blindly following her every decision regardless of how problematic that decision may be. In yet another twist of the story arc concerning the multiple faces of Otherness, here Ronald D. Moore clearly depicts the monstrosity that is within us all, not only the Cylons but also the human survivors of the apocalypse. In particular concerning the case of Helen Cain, somehow the viewer is not so sad when she is assassinated by one of the Number Sixes ${ }^{15}$ !

All of these elements beg the question of how Battlestar Galactica contributes to the resolution of political, social and moral issues raised by the War on Terror and more generally post-9/11 America. I would contend that it functions in fact as a powerful

15 This scene in Razor in which Admiral Cain executes her X-O who refuses to implement a battle order in the face of overwhelming odds in favor of the Cylons (see Razor, 33'56" and onwards) seems curiously reminiscent of the scene in Little Big Man (Arthur Penn, 1970) in which an officer questions Custer's decision to descend into the midst of 2,00o Indians and attack them "by surprise". 
counter-narrative by using the political fiction dimension of science fiction to its fullest effect. In a style reminiscent of revisionist historiography and its impact on American science fiction writing of the 1970s, Battlestar Galactica deconstructs the hegemonic discourse and hero glorification of the traditional war narrative to produce in its stead "a narrative in which governmental authority is repeatedly questioned while fantasies of control and power are undermined or problematized ${ }^{16}$." Adama's speech on the Cylon War in the pilot episode is emblematic of this questioning of authority:

[ADAMA] (addressing assembly of the fleet): The Cylon war is long over yet we must not forget the reasons why so many sacrificed so much in the cause of freedom. The cost of wearing the uniform can be high, but... (long silence, shots of Tigh, Roslin and Doral in the audience waiting for what follows, looking pained/embarrassed; Adama removes his glasses and stops reading his speech) ... sometimes it's too high. We thought that when we fought the Cylons we did it to save ourselves from extinction but we never answered the question "why?" Why are we as a people worth saving? We still commit murder because of greed and spite, jealousy, and we still visit all of our sins upon our children (cut to space, and pan shot to Apollo in his Viper listening to the speech over the radio). We refuse to accept responsibility for anything we've done, like we did with the Cylons. We decided to play God, create life (shot to Starbuck in the brig, listening to the speech over a loud speaker); when that life turned against us, we comforted ourselves in the knowledge that it really wasn't our fault, not really. You cannot play God then wash your hands of the things that you have created. Sooner or later, the day comes when you can't hide from the things you've done any more (leaves the stage in silence, no applause).

Although he begins with the expected call to sacrifice in the name of freedom, he can no longer see the justification of war, his discourse disintegrating into a calling into question of the very nature of global conflict and its consequences that go well beyond the present, and boil over into a dark tomorrow where future generations will pay for the sins committed by their ancestors. At the same time the subversion of the essentializing rhetoric of Otherness, especially through the inversion of religious discourse, produces uncertainty both within the series and in the viewer, as the difference between the good "us" and the evil "them" becomes progressively blurred. Beyond the surface reading of the speech in its context (Adama has just had a heated discussion with his son who blames him for Zack's death), the greater sense of Adama's soul-searching is to be grasped outside the frame of the show itself: in the viewer's frame of reference, Adama's comments on "passing the buck" of responsibility onto future generations resonates in the context of the War on Terror. This is perhaps the most ingenious aspect of the series; as the story unfolds, the viewers become

${ }^{16}$ Rawle, p. 139. 
caught up in the anti-Cylon paranoia of the human characters, a powerful reminder of how easy it is to be manipulated by what Melnick, when speaking about the War on Terror, calls "the power of the official rhetorics of national victimhood [which] serve to obscure who is really being terrorized ${ }^{17}$." And despite Battlestar Galactica's militaristic themes and settings, the series is in fact fundamentally anti-militaristic in nature, denouncing the futility of war, the dangers of post-human technology and the hollowness of battles fought in the name of religious creeds.

We can say then that rather than implementing the conceptual breakthrough of the traditional science fiction story, Moore is using the principle of cognitive estrangement to test our capacity to deal with the traumatic reality of annihilation and its impact on how society evolves in the aftermath, a definite challenge for post-9/11 America. By removing the trauma from the realm of some idealizing cultural fantasy of glossy battles and heroic leaders, and by recontextualizing it in the gritty verisimilitude of more problematic war narratives such as Band of Brothers (HBO mini-series, 2001) or Saving Private Ryan (dir. Steven Spielberg, 1998) Moore undoubtedly seeks to challenge the limits of our own cultural attitudes towards identity, power and ultimately what it means to be human.

\section{Bibliography}

EBERL Jason, ed., Battlestar Galactica and Philosophy: Knowledge Here Begins Out There, Blackwell Philosophy and Popculture Series, Oxford, Blackwell, 2008 (Kindle edition).

BASSOm David, Battlestar Galactica: The Official Companion Season 3, London, Titan Books, 2007.

Faludi Susan, The Terror Dream: Fear and Fantasy in Post-9/11 America, New York, Picador, 2008 (Kindle edition).

Melnick Jeffrey, 9/11 Culture: America under Construction, Malden, Mass., Wiley-Blackwell, 2009 (Kindle edition).

MOORE Ronald D., Battlestar Galactica, The Series Bible, pdf version of manuscript dated December 17 2003, downloaded from http://www.harvardwood.org/resource/resmgr/hwppdfs/battlestar_galactica_series.pdf August 262012.

${ }_{17}$ Melnick, p.135 
RAWLE Steven, "Re-imagining Terror in Battlestar Galactica: Negotiating Real and Fantasy in Battlestar Galactica's Political Metaphor" in Battlestar Galactica: Investigating Flesh, Spirit and Steel, ed. Roz Kaveney and Jennifer Stoy, New York, IB Tauris, 2010, p. 129-153 (Kindle edition).

SLOTKIN Richard, The Fatal Environment: The Myth of the Frontier in the Age of Industrialization 1800-1890, New York, Harper Perennial, 1985 .

\section{The author}

Donna Spalding Andréolle is a professor of American studies at the Université du Havre (France) where she teaches American history and culture courses as well as a Master's seminar on TV series. Her research centers on 'lowbrow' cultural objects as sites of social commentary as well as on representations of scientific progress in science fiction novels and Hollywood productions since the mid-twentieth century.

Some of her most recent publications and conference papers explore the cultural and ideological dimensions of contemporary American society in series such as Star Trek the Original Series, The Middle, Big Love, True Blood and Homeland. She is also co-editor of two books, Science and Empire in the Nineteenth Century: A Journey of Conquest and Scientific Progress (with Catherine Delmas and Christine Vandamme, CSP, 2010) and Women and Science, Seventeenth Century to Present: Pioneers, Activists and Protagonists (with Veronique Molinari, CSP, 2011), and is currently writing a book on Friends for les Presses Universitaires de France. 